\title{
Een onderzoek naar post-stroke epilepsie
}

Op I6 april 202I promoveerde Julia van Tuijl aan de Universiteit Maastricht op het proefschift Post-stroke epilepsy . Haar klinisch gerichte onderzoek geeft nieuwe inzichten in de epilepsie zoals deze kan ontstaan na een beroerte (herseninfarct of hersenbloeding), de post-stroke epilepsie.

In Nederland krijgen per jaar rond de 43.000 mensen een beroerte, van wie tussen de $2 \%$ en $14 \%$ epileptische aanvallen krijgt. Het risico op het krijgen van epileptische aanvallen en epilepsie na een beroerte is afhankelijk van de grootte, aard (bloeding of infarct) en plaats (is er betrokkenheid van de hersenschors?) van de beroerte. Aangezien beroerte meer voorkomt bij toenemende leeftijd, zorgt de vergrijzing ervoor dat ook het voorkomen van post-stroke epilepsie toeneemt. Julia van Tuijl onderzocht de gevolgen van post-stroke epilepsie, hoe poststroke epilepsie behandeld wordt en of het ook voorkómen kan worden.

\section{Invloed op het overlijden}

Om te bepalen of er een verband is tussen het optreden van epileptische aanvallen na een beroerte en overlijden op langere termijn onderzocht zij 444 patiënten met een herseninfarct. Daarvan kregen er zestien vroege aanvallen (binnen één week na de beroerte) en 32 late aanvallen (meer dan één week na de beroerte). In beide gevallen vond zij geen onafhankelijk verband tussen aanvallen en mortaliteit (van Tuijl et al., 2018).

\section{Invloed op handicap en kwaliteit van leven}

In een case-control studie werden 36 patiënten met epilepsie na een beroerte onderzocht en vergeleken met patiënten met zo goed mogelijk gematchte patiënten van dezelfde leeftijd en geslacht, en met dezelfde aard, grootte en zijde van de beroerte, echter zonder epilepsie (van Tuijl et al., 2020). De patiënten met epilepsie hadden lagere scores op neurologische uitvalsverschijnselen (gemodificeerde Rankin score, NIHSS), lagere scores bij een cognitieve test die informatieverwerkingssnelheid meet, en een lagere ziekte-specifieke kwaliteit van leven. Mogelijk speelt het herstelproces en de invloed van de epilepsie daarbij ook een rol, al kon dit niet verder onderzocht worden.

\section{Behandeling}

In een groep van 53 patiënten met post-stroke epilepsie werd onderzocht welke medicatie zij gebruikten en of zij wisselden van medicatie. In deze studiegroep waren carbamazepine, levetiracetam, fenytoïne en valproaat de gebruikte middelen. Bij een opvolgingsduur van mediaan 62 maanden wisselden in totaal 2I patiënten (40\% van de gehele groep) van medicatie, van wie zeven vanwege onvoldoende aanvalsreductie wisselden en zestien vanwege bijwerkingen (twee vanwege beide), vaak waren de doseringen niet hoog (Bekelaar et al., 2020).

Uit deze zeer relevante klinische studies wordt duidelijk dat post-stroke epilepsie een behoorlijke impact heeft op het leven van patiënten, zowel qua kwaliteit van leven als mate van invaliditeit. In de navolgende studies heeft Julia van Tuijl daarom uitgezocht of er preventie mogelijk is van post-stroke epilepsie.

\section{De ETLAS-studie}

In deze gerandomiseerde placebogecontroleerde dubbelblinde studie, werd onderzocht of het geven van levetiracetam na een corticaal gelegen bloeding of infarct epilepsie voorkómt (van Tuijl et al., 20II). Het preventief gebruik bestond uit tweemaal daags $750 \mathrm{mg}$ levetiracetam gedurende de eerste twaalf weken. De studie is echter voortijdig beëindigd vanwege een lage inclusiesnelheid. Dit onderzoek is een duidelijk voorbeeld van de problemen die bij studies in deze populatie optreden. Dit zijn:

I Overschatting van het aantal patiënten die geschikt zijn voor de studie (mede omdat er weinig zicht is op factoren die daar invloed op hebben, zoals comorbiditeit of exclusiecriteria).

2 De uitkomstmaat (epileptische aanval) is zeer lastig om betrouwbaar te registreren.

3 Het registreren van bijwerkingen (vanwege de comorbide problemen door de beroerte zijn vaak lastig te onderscheiden).

${ }^{1}$ Promotor: Prof. Dr. A.P. Aldenkamp, Co-promotoren: Dr. R.P.W. Rouhl en Dr. E.P.M. van Raak, neurologie, Maastricht UMC+ 
4 Trialmedicatie werd vaak gestopt buiten het ziekenhuis om (waardoor de twaalf weken behandelduur niet werden voltooid).

Dit deel van het proefschrift legt heel duidelijk de vinger op de zere plek: onderzoek doen naar dit belangrijke klinische probleem in een kwetsbare patiëntenpopulatie is bijzonder lastig en kent vele haken en ogen die het welhaast onmogelijk maken om methodologisch gedegen onderzoek uit te voeren.

\section{De EGASIS-studie}

Om toch een uitspraak te doen over de vraag of het mogelijk is om epileptische aanvallen na een beroerte te voorkomen, maakte van Tuijl gebruik van de data van een grote multicenter studie, de EGASIS-studie, waarin (dubbelblind en gerandomiseerd) een driedaagse kuur met diazepam na een beroerte werd onderzocht op neuroprotectieve eigenschappen. Het optreden van epileptische aanvallen was een geregistreerd eindpunt van deze studie. Het bleek dat patiënten in de groep die diazepam gebruikten in de eerste drie maanden minder vaak epileptische aanvallen hadden, met name wanneer de beroerte zich bevond in het deel van de hersenen dat van bloed wordt voorzien door de voorste circulatie (0,9\% van deze patiënten kreeg een aanval bij gebruik diazepam versus $4,6 \%$ in de placebogroep; IRR 0,20; 95\%-BI 0,05-0,78, p=0,02). Deze studie lijkt erop te wijzen dat een korte behandeling met diazepam net na de beroerte gunstige effecten kan hebben op de langere termijn (drie maanden) als het gaat om het vóórkomen van epileptische aanvallen (van Tuijl et al., 202I).

\section{Conclusie}

In haar proefschrift beschrijft Julia van Tuijl haar uitstekend en consciëntieus uitgevoerde klinische onderzoek.

Ze toont zich een kritisch wetenschapper die haar onderzoek goed op de juiste waarde kan schatten. Haar studies tonen ook mooi het voortschrijdend inzicht in het veld van de post-stroke epilepsie, maar helaas blijkt ook dat studies naar medicatie ter preventie van het ontstaan van epilepsie na een beroerte zeer lastig uitvoerbaar zijn.

\section{Referenties}

Bekelaar, K., Van Tuijl, J. H., Van Raak, et al. 2020. Medication use in poststroke epilepsy: A descriptive study on switching of antiepileptic drug treatment. Epilepsy Behav, I04, Io6434.

Van Tuijl, J. H., Van Raak, E. P., De Krom, M. C., et al. 20II. Early treatment after stroke for the prevention of late epileptic seizures: a report on the problems performing a randomised placebo-controlled double-blind trial aimed at anti-epileptogenesis. Seizure, 20, 285-9I.

Van Tuijl, J. H., Van Raak, E. P. M., Van Oostenbrugge, et al. 2018. The occurrence of seizures after ischemic stroke does not influence long-term mortality; a 26-year follow-up study. J Neurol, 265, I780-I788.

Van Tuijl, J. H., Van Raak, E. P. M., Van Oostenbrugge, et al. 2020. Cognition and quality of life in patients with poststroke epilepsy: A case-control study. Epilepsy Behav, I04, I06444.

Van Tuijl, J. H., Van Raak, E. P. M., Van Oostenbrugge, et al. 202I. Treatment with Diazepam in Acute Stroke Prevents Poststroke Seizures: A Substudy of the EGASIS Trial. Cerebrovasc Dis, 50, 2I6-22I. 